\title{
RESEARCH
}

Open Access

\section{Sinusoidal electromagnetic fields accelerate bone regeneration by boosting the multifunctionality of bone marrow mesenchymal stem cells}

Weigang Li $i^{1}$, Wenbin Liư ${ }^{2}$, Wei Wang ${ }^{1}$, Jiachen Wang ${ }^{3}$, Tian Ma ${ }^{1}$, Jingyuan Chen ${ }^{4}$, Hua Wu ${ }^{1 *}$ (D) and Chaoxu Liu ${ }^{1 *}$

\begin{abstract}
Background: The repair of critical-sized bone defects is always a challenging problem. Electromagnetic fields (EMFs), used as a physiotherapy for bone defects, have been suspected to cause potential hazards to human health due to the long-term exposure. To optimize the application of EMF while avoiding its adverse effects, a combination of EMF and tissue engineering techniques is critical. Furthermore, a deeper understanding of the mechanism of action of EMF will lead to better applications in the future.

Methods: In this research, bone marrow mesenchymal stem cells (BMSCs) seeded on 3D-printed scaffolds were treated with sinusoidal EMFs in vitro. Then, $5.5 \mathrm{~mm}$ critical-sized calvarial defects were created in rats, and the cell scaffolds were implanted into the defects. In addition, the molecular and cellular mechanisms by which EMFs regulate BMSCs were explored with various approaches to gain deeper insight into the effects of EMFs.

Results: The cell scaffolds treated with EMF successfully accelerated the repair of critical-sized calvarial defects. Further studies revealed that EMF could not directly induce the differentiation of BMSCs but improved the sensitivity of BMSCs to BMP signals by upregulating the quantity of specific BMP (bone morphogenetic protein) receptors. Once these receptors receive BMP signals from the surrounding milieu, a cascade of reactions is initiated to promote osteogenic differentiation via the BMP/Smad signalling pathway. Moreover, the cytokines secreted by BMSCs treated with EMF can better facilitate angiogenesis and osteoimmunomodulation which play fundamental roles in bone regeneration.
\end{abstract}

Conclusion: In summary, EMF can promote the osteogenic potential of BMSCs and enhance the paracrine function of BMSCs to facilitate bone regeneration. These findings highlight the profound impact of EMF on tissue engineering and provide a new strategy for the clinical treatment of bone defects.

Keywords: Stem cells, Sinusoidal electromagnetic field, BMP receptors, Osteogenesis, Angiogenesis, Osteoimmunomodulation, Bone tissue engineering

\footnotetext{
* Correspondence: wuhua@hust.edu.cn; chaoxuliu@hotmail.com

'Department of Orthopedics, Tongji Hospital, Tongji Medical College,

Huazhong University of Science and Technology, Wuhan 430030, Hubei,

China

Full list of author information is available at the end of the article
}

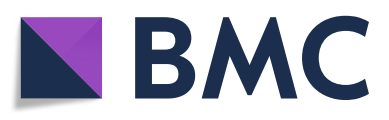

(- The Author(s). 2021 Open Access This article is licensed under a Creative Commons Attribution 4.0 International License, which permits use, sharing, adaptation, distribution and reproduction in any medium or format, as long as you give appropriate credit to the original author(s) and the source, provide a link to the Creative Commons licence, and indicate if changes were made. The images or other third party material in this article are included in the article's Creative Commons licence, unless indicated otherwise in a credit line to the material. If material is not included in the article's Creative Commons licence and your intended use is not permitted by statutory regulation or exceeds the permitted use, you will need to obtain permission directly from the copyright holder. To view a copy of this licence, visit http://creativecommons.org/licenses/by/4.0/ The Creative Commons Public Domain Dedication waiver (http://creativecommons.org/publicdomain/zero/1.0/) applies to the data made available in this article, unless otherwise stated in a credit line to the data. 


\section{Background}

Bone, as one of the most extensive and universal organs in the human body, is of great significance to human health. The failure of bone function not only leads directly to a reduced quality of life but also imposes a staggering financial burden on the health care system [1-3]. Bone grafting is a common surgical method to augment bone regeneration [4]. Among all clinically available grafts, autologous bone is still considered the gold standard. Nevertheless, autologous bone grafts possess the disadvantages of poor availability, donor-site morbidity and prolonged operation time [5-7].

In an effort to circumvent these limitations, bone tissue engineering (BTE) has grown in popularity and is currently being studied as a possible alternative to fracture management [8]. With the development of BTE, an increasing number of new materials have been developed as bone substitutes. In addition, the selection of stem cell sources, growth factors and mechanical stimulation is continuously being optimized to boost the osteogenic properties of synthetic bone.

Bone marrow mesenchymal stem cells (BMSCs) are currently the most common source of stem cells in bone tissue engineering due to their relative ease of acquisition, high proliferative ability and established regenerative potential $[9,10]$. Moreover, BMSCs have been extensively studied and found to enhance angiogenesis by secreting pro-angiogenic factors and play a vital role in osteoimmunomodulation [11-14].

The electrical environment is one of the most important microenvironments in which bone tissue exists. The outer electromagnetic fields (EMFs) have a vital effect on bone tissue and osteoblasts. Since Bassett et al. first proposed in 1974 that electromagnetic fields can promote osteogenesis [15], the effect of EMF on bone regeneration has been extensively studied. EMF has been successfully employed as an adjunctive therapy for the treatment of orthopedic disorders such as spinal cord injury, fresh fractures and delayed fractures [16-18]. However, prolonged exposure to EMF can lead to an increased risk of certain cancers, Alzheimer's disease, male infertility and other conditions [19]. This may be attributed to the genotoxic effects, neurological effects and carcinogenicity of EMF [20-22]. The combination of EMF and tissue engineering technology may optimize clinical treatments with EMF in bone regeneration while avoiding its adverse effects. More importantly, deep insights into the mechanisms by which EMF regulate BMSCs will improve the use of EMF in the future. Therefore, in this research, a 3D-printed scaffold loaded with BMSCs stimulated by low-frequency sinusoidal electromagnetic fields $(15 \mathrm{~Hz}, 0.3 \mathrm{mT})$ was utilized to repair bone defects, and its role in bone repair was examined in detail. The selection of EMF parameters was based on the previous research by our team [23-25].

It has been widely reported that a PCL (polycaprolactone)/HA (hydroxyapatite) composite material demonstrates enhanced osteogenic ability in bone repair [26, 27 ] and that polydopamine coating can improve cell adhesion $[28,29]$. Therefore, in this study, polydopaminecoated scaffolds made of PCL and HA were used as cell carriers. Moreover, the molecular and cellular mechanisms by which sinusoidal EMF regulates BMSCs were investigated in vitro. To date, all research that has been conducted has aimed at exploring the regulatory effects of EMF on BMSCs and optimizing the application of EMF in the clinic while avoiding its adverse effects.

\section{Materials and methods \\ Manufacture of PCL/HA hybrid scaffolds}

PCL and HA were dissolved in an excess of dichloromethane at a ratio of 7:3 and the solution was mixed uniformly on a magnetic stirrer. Over several hours of volatilization of methylene chloride at room temperature, the solution gradually became viscous. Then, a cross-linked porous scaffold was fabricated layer by layer with an FDM (fused deposition modeling) 3D printer. The size of the scaffold used in vitro was $8 \mathrm{~mm}$ in length and $1 \mathrm{~mm}$ in thickness. These porous scaffolds were cut into discs with a diameter of $5.5 \mathrm{~mm}$ for in vivo trials. Finally, the scaffolds were placed in a draught cupboard overnight to vapourize the remaining methylene chloride.

\section{Polydopamine surface coating}

The method for polydopamine coating has previously been reported in "Science" [30]. In brief, dopamine powders were dissolved in $10 \mathrm{mM}$ Tris- $\mathrm{HCl}$ ( $\mathrm{pH} \mathrm{8.5)}$ to prepare a $2 \mathrm{mg} / \mathrm{ml}$ dopamine Tris-HCL solution. Immediately afterwards, the porous scaffolds were immersed into the dopamine Tris-HCL solution and stirred overnight at room temperature. The scaffold surface modified by polydopamine changed from white to brown. The coated scaffolds were rinsed with ultrapure water 3 times and placed in a drying oven. Finally, these scaffolds were sent to the hospital for sterilization with ethylene oxide.

\section{Cell culture}

Rat bone marrow mesenchymal stem cells purchased from Cyagen Biotechnology Co., Ltd. (Suzhou, China) were cultured in $\alpha$-MEM supplemented with $10 \%$ foetal bovine serum (Gibco, 10091148, NY, USA), $100 \mathrm{U} / \mathrm{ml}$ penicillin and $100 \mathrm{U} / \mathrm{ml}$ streptomycin (Sigma-Aldrich, A5955, USA). Then, $10 \mathrm{mM} \beta$-glycerophosphate, $50 \mathrm{mg} /$ 
$\mathrm{ml}$ ascorbic acid and $10 \mathrm{nM}$ dexamethasone were added to complete $\alpha$-MEM to prepare osteogenic medium $(\mathrm{OM})$. On a vertical flow clean bench, sterilized scaffolds were placed in 24-well plates and washed 3 times with phosphate-buffered saline (PBS). Next, they were incubated in $\alpha$-MEM without foetal bovine serum for $2 \mathrm{~h}$ before cell seeding. BMSCs at passage 3 were seeded on the scaffolds and cultured with $\alpha$-MEM complete medium at $37^{\circ} \mathrm{C}, 5 \% \mathrm{CO}^{2}$ and $95 \%$ humidity. Then, cellseeded scaffolds were transferred to new 24-well plates the next day, and the culture medium was changed every 2 days.

\section{Sinusoidal electromagnetic field stimulation system}

The EMF stimulation system that has been used in our previous studies [31, 32] consists of an EMF generator, an amplifier, an oscilloscope and a pair of Helmholtz coils that are $30 \mathrm{~cm}$ in diameter and $15 \mathrm{~cm}$ apart (Fig. 1b). The system was designed and manufactured by the Naval University of Engineering (Wuhan, China). EMFs with adjustable intensity and frequency $(0-5 \mathrm{mT}$, $1-200 \mathrm{~Hz}$ ) were generated by these devices. Helmholtz coils were positioned in an incubator with $5 \% \mathrm{CO}_{2}$ and $95 \%$ humidity at $37^{\circ} \mathrm{C}$. Cell-seeded scaffolds assigned to the N-EMF and O-EMF groups were exposed to a sinusoidal electromagnetic field $(15 \mathrm{~Hz}, 0.3 \mathrm{mT})$ for $4 \mathrm{~h}$ each day.

\section{Cell viability}

BMSCs $\left(4 \times 10^{4}\right)$ were seeded into a 24 -well plate in which a scaffold was ensconced, and the proliferation of cells was detected by Cell Counting Kit-8 assay (CCK-8, Dojindo, CK04, Japan) after culturing for 1, 3 and 5 days. In brief, complete $\alpha$-MEM and CCK- 8 solution were mixed at a ratio of 9:1 to configure a working solution. Two milliliters working solution was added to each well to submerge the scaffold before the cell-seeded scaffolds were incubated at $37^{\circ} \mathrm{C}$ for $2 \mathrm{~h}$. The absorbance was measured at $450 \mathrm{~nm}$ using a microplate reader (Bio-Rad, USA). A live-dead kit (Thermo Fisher, L3224, USA) was used to evaluate cell cytotoxicity according to the instructions after 1,3 and 5 days of culture. The BMSCs were imaged using a fluorescence microscope (EVOS FL Auto, Life Technologies, USA).

\section{Cell morphology}

BMSCs $\left(4 \times 10^{4}\right)$ were seeded into a 24-well plate in which a scaffold was ensconced. After 3 days and 7 days of culture under the appropriate conditions, the cell-seeded scaffolds were washed twice with PBS and fixed with $2.5 \%$ glutaraldehyde at $4{ }^{\circ} \mathrm{C}$ for $4 \mathrm{~h}$. Then some of the cell scaffold constructs were dehydrated through an ethanol gradient (50, 60, 70, 80, 90 and 100\%), followed by drying in vacuum. The dehydrated samples were coated with a layer of gold by an ion sputtering instrument (Q150R S, Quorum Technologies, UK) prior to scanning electron microscopy (SEM) observation (VEGA 3 LMU, Tescan, $\mathrm{CZ}$ ); the remaining scaffolds were permeabilized with $0.5 \%$ Triton X-100 solution for $5 \mathrm{~min}$ and then washed 2 times with PBS. Subsequently, the samples were soaked with the prepared TRITC-phalloidin working solution (Solarbio, CA1610, Beijing, China) and incubated at room temperature for $30 \mathrm{~min}$ in the dark. After washing 3 times in PBS, the nuclei were stained with $100 \mathrm{nM}$ DAPI (Solarbio, C0060, Beijing, China) solution for $30 \mathrm{~s}$. Finally, the processed samples were observed with a confocal microscope (Eclipse, NIKON, Japan).

\section{Modelling of calvarial defects in rats}

Fifteen male SD rats ( 10 weeks, $300-350 \mathrm{~g}$ ) were provided by the Laboratory Animal Center of Tongji Hospital. All procedures were approved by the Animal Care and Use Committee of Huazhong University of Science and Technology. The provided rats were used to create a cranial bone defect model for an in vivo study as previously described [33]. In brief, the rats were anaesthetized with 5\% chloral hydrate. After shaving and disinfecting the surgical site, the skin and subcutaneous tissue were cut to expose the skull. Then two penetrating skull defects with a diameter of $5.5 \mathrm{~mm}$ were created on both sides of the midline of the skull with a ring drill. The periosteum was completely removed from the skull surface by scraping, while the dura mater remained intact. Cell scaffolds that had been cultured for 1 week in OM with or without EMF were embedded in the defect site. The scaffolds were covered with soft tissue, and the incision was sutured with surgical sutures. The 15 operated rats were divided into 3 groups $(n=10)$ and treated as follows: (1) Blank group: Nothing was implanted into the defective skull. (2) O-N group: The cell scaffolds cultured with $\mathrm{OM}$ were implanted in the defect sites. (3) O-EMF group: Rats were implanted with cell scaffolds treated by EMF under OM. All of the rats were euthanized by rapid injection of an excess of $10 \%$ chloral hydrates at 8 weeks after surgery. Retrieved samples were fixed in $10 \%$ formalin for 2 days and then transferred to $70 \%$ ethanol for further analysis.

\section{Computed tomography (CT) and histological analysis}

A Bruker Micro-CT SkyScan 1276 system (Kontich, Belgium) with an isotropic voxel size of $6.5 \mu \mathrm{m}$ was used to image the skull, and reconstruction was accomplished by NRecon (version 1.7.4.2). The percentage of new bone volume relative to tissue volume (BV/TV) and the bone mineral density (BMD) were calculated by CT Analyser software (version 1.18.8.0) to assess the healing of bone defects. After this assessment, specimens were processed into $50-\mu \mathrm{m}$-thick undecalcified sections and stained with haematoxylin-eosin (H\&E), Masson 


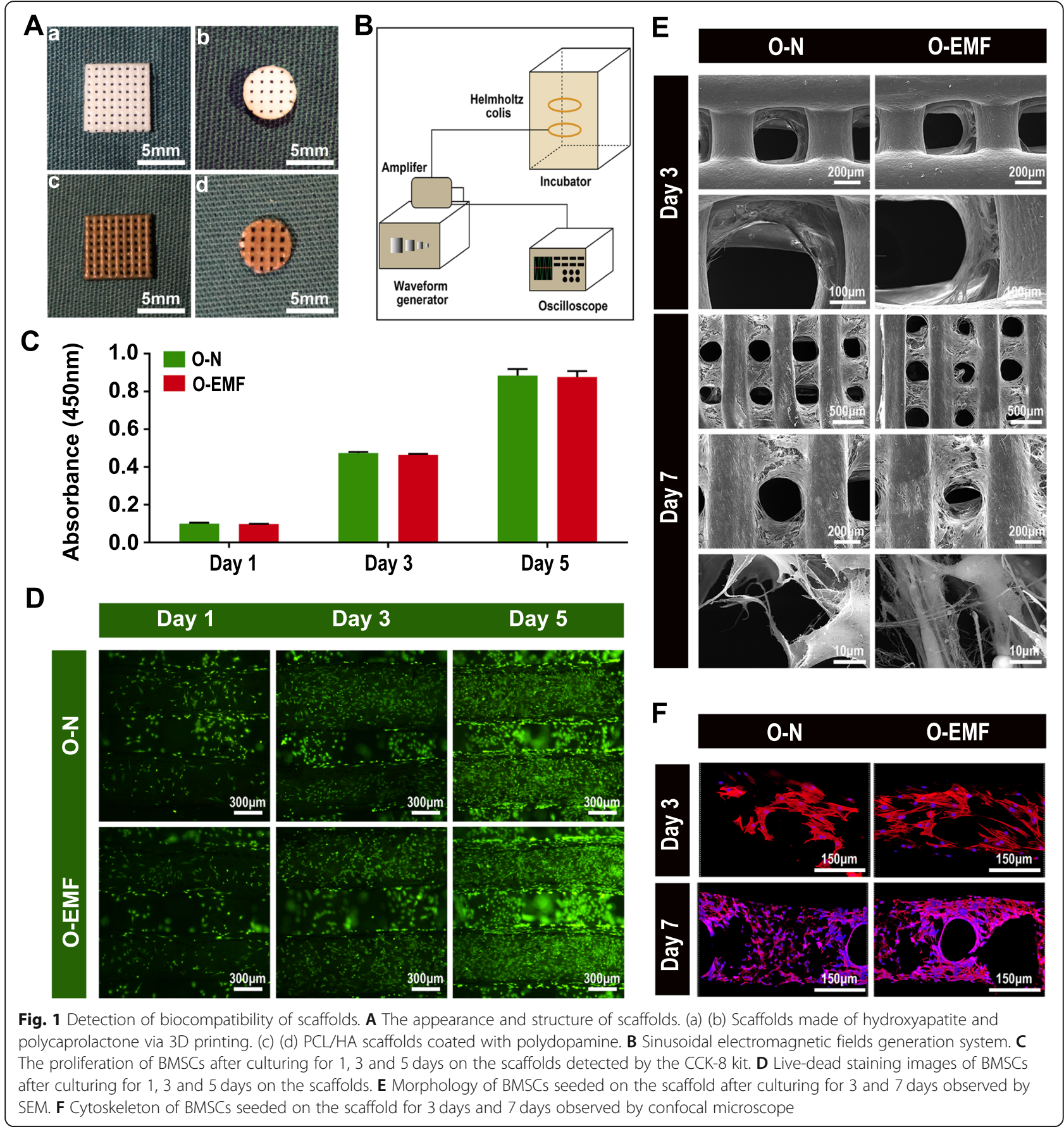

trichrome and von Kossa to further explore the bone formation in the defect sites in each group. The new bone area fraction, calculated as the new bone area/defect area within the defect of each section, was obtained using ImageJ software $(n=10)$.

Alkaline phosphatase (ALP), collagen and mineralization assays

To further explore the mechanism by which EMF regulates BMSCs, the cells were randomly distributed into four groups: (1) N-N group: cells were cultured in normal medium ( $\alpha$-MEM) without EMF intervention; (2) N-EMF group: cells were cultured in normal medium with EMF intervention; (3) O-N group: cells were cultured in osteogenic medium without EMF intervention; (4) O-EMF group: cells were cultured in osteogenic medium with EMF intervention. A total of $1 \times 10^{4}$ cells were seeded in 24 -well plates and fixed with $4 \%$ paraformaldehyde after 7 days of culture. ALP and collagen were stained with a BCIP/NBT alkaline phosphatase 
colour development kit (Beyotime, China) and Sirius red (Sigma, USA), respectively. Mineralization was detected by Alizarin Red (Cyagen, China). The staining-positive area fraction, calculated as the staining-positive area/ total area, was obtained using ImageJ software $(n=6)$.

\section{Analysis of gene expression}

A total of $2 \times 10^{5}$ cells were seeded into a 24-well plate positioned with a scaffold, and intervention was started the day after the scaffold was transferred to a 12-well plate. Total RNA was extracted from the cell scaffold constructs using the RNeasy Kit (Omega, R6834-01, USA) after 4 days of culture. A total of $1 \mu \mathrm{g}$ of RNA was reverse transcribed using the Reverse Transcriptase Kit (Toyobo, FSQ-101, Japan). Relative expression of bone morphogenetic protein 2 (BMP2), bone sialoprotein (BSP), runt-related gene 2 (Runx2), osteocalcin (OCN) and osteopontin $(\mathrm{OPN})$ was detected by quantitative real-time PCR (RT-qPCR). Gene-specific primers (Tables 1 and 2) purchased from Tsingke Biotechnology Company (Beijing, China) were used to amplify the cDNA in a Bio-Rad myiQ2 thermal cycler (Bio-Rad, Hercules, CA, USA), of which GAPDH was used as the internal control for target mRNA. The RT-qPCR cycling conditions were $95^{\circ} \mathrm{C}$ for $30 \mathrm{~s}$ followed by 40 cycles of $94^{\circ} \mathrm{C}$ for $5 \mathrm{~s}$ and $60^{\circ} \mathrm{C}$ for $35 \mathrm{~s}$. Melt curve analyses were performed on each primer set to minimize primerdimers and nonspecific products. The $2^{-\Delta \Delta \mathbf{C t}}$ method was used to analyse the relative expression of target mRNA. The experimental grouping is the same as in section "Alkaline phosphatase (ALP), collagen and mineralization assays".

\section{Western blot analysis}

The proteins were analysed from whole-cell lysates of cells cultured in each group after 7 days. The protein concentration was measured by BCA protein assay reagent (Boster, Wuhan, China). Then $40 \mu \mathrm{g}$ protein samples were separated by SDS-polyacrylamide gels and transferred to PVDF membranes. The membranes were then blocked with $5 \%$ bone serum albumin for $1 \mathrm{~h}$ and incubated with primary antibodies (COL1, BMP2 at 1 : 1000 dilution, $\beta$-actin at 1:5000 dilution, Abcam, UK; OCN at 1:1000 dilution, Santa Cruz Biotechnology) at $4{ }^{\circ} \mathrm{C}$ overnight. Next, blots were incubated with horseradish peroxidase (HRP)-conjugated secondary antibodies (goat anti-rabbit and goat anti-mouse antibodies at a 1:5000 dilution, Boster, China) for $1 \mathrm{~h}$. The bands were detected by the Western ECL Substrate Kit (Thermo Pierce, USA). The proteins were normalized to $\beta$-actin. The experimental grouping is the same as in section "Alkaline phosphatase (ALP), collagen and mineralization assays".
Table 1 Specific primers used in this study

\begin{tabular}{|c|c|c|}
\hline Gene (rat) & & Primer sequences \\
\hline Smad1 & $\begin{array}{l}\text { Forward: } \\
\text { Reverse: }\end{array}$ & $\begin{array}{l}\text { CAGCCCTITTCAGATGCCAG } \\
\text { ACTGCTTGAACATCTCCTCTATTG }\end{array}$ \\
\hline Smad4 & $\begin{array}{l}\text { Forward: } \\
\text { Reverse: }\end{array}$ & $\begin{array}{l}\text { GGTCCGTAGGTGGAATAGCC } \\
\text { AATCCAGCACGGGGTITCTT }\end{array}$ \\
\hline Smad5 & $\begin{array}{l}\text { Forward: } \\
\text { Reverse: }\end{array}$ & $\begin{array}{l}\text { CTGCCAATAACAAGAGCCGC } \\
\text { ACCTCCCCACCAACGTAGTA }\end{array}$ \\
\hline Smad8 & $\begin{array}{l}\text { Forward: } \\
\text { Reverse: }\end{array}$ & $\begin{array}{l}\text { AACAACCAGCTCTTCGCCC } \\
\text { CTGGCGATGATACTCGGCTC }\end{array}$ \\
\hline ACVR1 & $\begin{array}{l}\text { Forward: } \\
\text { Reverse: }\end{array}$ & $\begin{array}{l}\text { GACTGTACGCTGTCAGGCTC } \\
\text { CCATACTCGGGGAAGGGAGA }\end{array}$ \\
\hline BMPR1A & $\begin{array}{l}\text { Forward: } \\
\text { Reverse: }\end{array}$ & $\begin{array}{l}\text { GCACCAGAGGACACCTTACC } \\
\text { GCTGGGCTIITGGTGAATCC }\end{array}$ \\
\hline BMPR1B & $\begin{array}{l}\text { Forward: } \\
\text { Reverse: }\end{array}$ & $\begin{array}{l}\text { TTCTTCACCACGGAGGAAGC } \\
\text { AGTCCAAGACCCAGTCCCTT }\end{array}$ \\
\hline BMPR2 & $\begin{array}{l}\text { Forward: } \\
\text { Reverse: }\end{array}$ & $\begin{array}{l}\text { GAAGAGCACAGAGGCCCAAT } \\
\text { CCTGATTTGCCATCCTGCGT }\end{array}$ \\
\hline BMP2 & $\begin{array}{l}\text { Forward: } \\
\text { Reverse: }\end{array}$ & $\begin{array}{l}\text { GAAGAAATTGCAAAATGAAGACTGC } \\
\text { CGCCATCTCCATITCTTCCG }\end{array}$ \\
\hline BSP & $\begin{array}{l}\text { Forward: } \\
\text { Reverse: }\end{array}$ & $\begin{array}{l}\text { GAAGAAATTGCAAAATGAAGACTGC } \\
\text { CGCCATCTCCATITCTTCCG }\end{array}$ \\
\hline Runx2 & $\begin{array}{l}\text { Forward: } \\
\text { Reverse: }\end{array}$ & $\begin{array}{l}\text { CTACTCTGCCGAGCTACGAAAT } \\
\text { TCTGTCTGTGCCTTCTTGGTTC }\end{array}$ \\
\hline OPN & $\begin{array}{l}\text { Forward: } \\
\text { Reverse: }\end{array}$ & $\begin{array}{l}\text { CCAGCCAAGGACCAACTACA } \\
\text { CCAAGTGGCTACAGCATCTGA }\end{array}$ \\
\hline OCN & $\begin{array}{l}\text { Forward: } \\
\text { Reverse: }\end{array}$ & $\begin{array}{l}\text { GGAGGGCAGTAAGGTGGTGA } \\
\text { GAAGCCAATGTGGTCCGC }\end{array}$ \\
\hline VEGFA & $\begin{array}{l}\text { Forward: } \\
\text { Reverse: }\end{array}$ & $\begin{array}{l}\text { GGCCATCAAGCTCTCTCCTC } \\
\text { CACACACAGCCAAGTCTCCT }\end{array}$ \\
\hline FGF2 & $\begin{array}{l}\text { Forward: } \\
\text { Reverse: }\end{array}$ & $\begin{array}{l}\text { TGTCCATCAAGGGAGTGTGTG } \\
\text { TCGTITCAGTGCCACATACCA }\end{array}$ \\
\hline WWF & $\begin{array}{l}\text { Forward: } \\
\text { Reverse: }\end{array}$ & $\begin{array}{l}\text { GGTGGAGGAAGACCCCATTG } \\
\text { GATGTCCAGGTATGGCTCGG }\end{array}$ \\
\hline eNOS & $\begin{array}{l}\text { Forward: } \\
\text { Reverse: }\end{array}$ & $\begin{array}{l}\text { GAAGGTCGGTGTGAACGGAT } \\
\text { CCCATTTGATGTTAGCGGGAT }\end{array}$ \\
\hline GAPDH & $\begin{array}{l}\text { Forward: } \\
\text { Reverse: }\end{array}$ & $\begin{array}{l}\text { GAAGGTCGGTGTGAACGGAT } \\
\text { CCCATTTGATGTTAGCGGGAT }\end{array}$ \\
\hline
\end{tabular}

Table 2 Specific primers used in this study

\begin{tabular}{lll}
\hline Gene (mouse) & & Primer sequences \\
\hline IL-1 & Forward: & CCTGGACTGTGAGCATGGATA \\
& Reverse: & GTAAGGGGCGCATCAGGAC \\
IL-6 & Forward: & GGTGCCCTGCCAGTATTCTC \\
& Reverse: & GGCTCCCAACACAGGATGA \\
CD206 & Forward: & CTCTGCCATCACGTTAGTGAA \\
& Reverse: & GACGGTATCAAAACAACGCC \\
PDGFB & Forward: & CATCCGCTCCTITGATGATCTT \\
& Reverse: & GTGCTCGGGTATGTCAAGT \\
VEGFA & Forward: & CCACCTGCAAGACCATCGAC \\
& Reverse: & CTGGCGAGCCTAGTTGGAC \\
TGF- 3 & Forward: & TATTCAGCGGACTCACCAGC \\
& Reverse: & AACCAACCTCCTCAAACCGT \\
GAPDH & Forward: & TTCCAGGAGCGAGACCCCACTA \\
& Reverse: & GGGCGGAGATGATGACCCTTIT \\
\hline
\end{tabular}




\section{Detection of BMP signalling pathway}

The BMP signalling pathway is well known as an important pathway that can regulate cell fate in developing and mature tissues [34-36]. Moreover, BMP signalling is necessary and sufficient for osteogenesis [37-39]. To understand whether EMF affects the osteogenic properties of BMSCs by regulating the BMP signalling pathway, RNA of the cells stimulated by EMF for $4 \mathrm{~h}$ was immediately extracted. Subsequently, the expression levels of genes related to the BMP signalling pathway [type IA BMP receptor (BMPR1A/ALK3), type IB BMP receptor (BMPR1B), type II BMP receptor (BMPR2), type I activin receptor (ACVR1/ALK2), Smad1/5/8, Smad4)] were assayed by RT-qPCR. Furthermore, LDN193189, a selective BMP type I receptor inhibitor, was added to the $\mathrm{N}$-EMF and O-EMF groups at a concentration of 100 $\mathrm{nM}$ before the cells were stimulated by EMF to verify the regulatory effect of EMF on the BMP signalling pathway. In addition to the four groups in section "Alkaline phosphatase (ALP), collagen and mineralization assays", the two newly established groups were represented by N-EMF-I and O-EMF-I.

\section{Immunofluorescence staining}

BMSCs grown on coverslips were fixed in $4 \%$ paraformaldehyde and permeabilized with $0.5 \%$ Triton X-100 for $15 \mathrm{~min}$. Then the coverslips were blocked with ready-to-use goat serum for $30 \mathrm{~min}$. Immunostaining was carried out using primary antibodies including rabbit anti-phospho-Smad1/5/8 (1:100, Cell Signaling Technology), mouse anti-BMPRIB (1:50, Santa Cruz Biotechnology), rabbit anti-BMPRII (1:100, Absin Biosciences Inc., China), rabbit anti-Runx2 (1:100, Cell Signaling Technology), mouse anti-OPN (1:50, Santa Cruz Biotechnology) and mouse anti-OCN (1:50, Santa Cruz Biotechnology). The secondary antibodies were CY3-conjugated goat anti-rabbit IgG (1:200, Boster, China) and FITC-labeled goat anti-mouse IgG (1:200, Boster, China). The staining results were imaged on a confocal microscope (Eclipse, NIKON, Japan). Cell fluorescence quantitative analysis was performed by ImageJ software $(n=6)$.

\section{Collection of conditioned medium}

To explore the effect of EMF on the paracrine function of BMSCs, the collection of conditioned medium from BMSCs was necessary. After the cell scaffolds of the O$\mathrm{N}$ and O-EMF groups were cultured for 4 days, the medium was discarded and replaced with $\alpha$-MEM and incubated for another 4 days in a normal environment. Subsequently, the medium was collected, and 10\% FBS was added to generate a conditioned medium for the culture of the murine-derived macrophage cell line RAW264.7 (RAW) and endothelial progenitor cells
(EPCs). Both cell lines were purchased from Zhong Qiao Xin Zhou Biotechnology Co., Ltd. (Shanghai, China).

\section{Angiogenic effects of BMSCs}

After culturing EPCs with conditioned medium for 2 days, RT-qPCR was used to measure the expression level of angiogenic genes [von Willebrand factor (vWF), endothelial nitric oxide synthase (eNOS), fibroblast growth factors (FGF), vascular endothelial growth factor-A (VEGFA)]. At the same time, cells cultured with $\alpha$-MEM were used as a control group. To intuitively understand the effect of BMSCs on angiogenesis, we cultured EPCs grown on Matrigel with conditioned medium and observed tube formation at different times. Generally, the $100 \mu \mathrm{l}$ of Matrigel (Corning, USA) was placed into a 48well plate, then $2 \times 10^{4}$ cells were added to each well including $1 \mathrm{ml}$ of conditioned medium with $\alpha$-MEM as the control. Angiogenesis status was imaged under a microscope (Leica) after $4 \mathrm{~h}$ and $6 \mathrm{~h}$ of incubation. After $6 \mathrm{~h}$ of culture, the cells were stained with a live-dead kit (L3224, Thermo Fisher) and observed under a fluorescence microscope (EVOS FL Auto, Life Technologies, USA). The total length, number of segments and nodes in 6 randomly chosen fields were quantified using the Angiogenesis Analyzer macro in ImageJ [40].

\section{Osteoimmunomodulation of BMSCs}

To simulate the inflammatory environment in the early stage of fracture, lipopolysaccharide (LPS, $1 \mu \mathrm{g} / \mathrm{ml}$, Sigma) was added to the culture medium to activate RAW cells for $3 \mathrm{~h}$. Next, conditioned medium from the O-N and O-EMF groups was used to culture RAW cells. The cells cultured in $\alpha$-MEM were defined as the control group, and the inactive RAW cells were used as the blank group to be cultured in $\alpha$-MEM. After 1 day of incubation, the expression levels of macrophage polarization-related genes [interleukin-6 (IL-6), interleukin-1 $\beta$ (IL-1), CD206, transforming growth factor- $\beta 1$ (TGF- $\beta$ ), platelet-derived growth factor- $B$ (PDGFB), VEGFA)] were detected by RT-qPCR.

Cell surface markers (CD86 and CD206) related to macrophage polarization were detected by flow cytometry. In detail, each group of cells treated with the above methods was collected. Then RAW cells were washed 3 times with PBS and resuspended in $1 \%$ bovine serum albumin (BSA) for $15 \mathrm{~min}$ at $4{ }^{\circ} \mathrm{C}$ to block nonspecific antigens. Next, APC-CD206 antibody $(0.25 \mu \mathrm{g} / \mathrm{test}$, Thermo Fisher Scientific) and PE-CD86 antibody $(0.125 \mu \mathrm{g} /$ test, Thermo Fisher Scientific) were incubated with the RAW cells for $15 \mathrm{~min}$ at ambient temperature. After washing twice with PBS, cells were resuspended in $100 \mu \mathrm{l}$ of $1 \%$ BSA and analysed on a Guava flow cytometer (Millipore, USA). Data were analysed by Flowjo_ V10 software. 


\section{Statistical analysis and image editing}

To determine whether the differences between the two sets of data were statistically significant, a two-tailed homoscedastic $t$-test was applied. ${ }^{*} \#, \wedge,{ }^{\&} P<0.05$ was considered to be statistically significant; and ${ }^{* *, * \#, ~}$ \# $^{\wedge}, \& \& P<$ 0.01 was considered to be extremely significant; otherwise, results were considered not significant. Values are reported as the mean \pm standard deviation (SD). All in vitro experiments were performed at least three times. Brightness and contrast were adjusted equally across all images for improved visibility.

\section{Results}

\section{Characterization of the porous scaffold}

As shown in Fig. 1Aa, a porous scaffold with a side length of $8 \mathrm{~mm}$ and a height of $1 \mathrm{~mm}$ was manufactured by a $3 \mathrm{D}$ printer. The principal components of the scaffold are PCL and HA because PCL is a promising material for bone formation, and the presence of HA improves osteoblast activity [41]. Then, we processed the scaffold into a disc with a diameter of $5.5 \mathrm{~mm}$ and a thickness of $1 \mathrm{~mm}$ to meet the requirements for animal experiments (Fig. 1Ab). To increase the cell adhesion property of the scaffolds, the surface was coated with a layer of polydopamine [42]. The polydopamine particles were evenly distributed and bound to the surface of the scaffolds (Fig. 1Ac, d).

\section{Cells viability and morphology on scaffolds}

The proliferation of BMSCs seeded on scaffolds from the 4 groups was detected by CCK- 8 after culturing for 1,3 and 5 days. As shown in Fig. 1C, cells proliferated over time, but there was no significant difference between each group. Similar to the cell proliferation test, the live-dead test (Fig. 1D) also showed that cells seeded on scaffolds were healthy regardless of the EMF stimulation.

In addition to cell viability, the morphology of cells that adhered to the scaffolds was observed with SEM (Fig. 1E) and confocal microscopy (Fig. 1F). Most cells were completely attached to the surface of the scaffold on the 3rd day, while a small number of cells hung in the corner of the frameworks. By the 7th day, the scaffolds were densely covered with the cells. This illustrated that polydopamine-coated PCL/HA scaffolds exhibit superior biocompatibility, while EMF had little consequence on the proliferation and activity of BMSCs.

\section{Bone regeneration in vivo}

Animal trials were conducted to verify whether the combination of EMF and tissue engineering techniques can better promote bone regeneration in vivo. The $3 \mathrm{D}$ reconstructed rat craniums at 8 weeks are shown in Fig. 2a. Accordingly, there was almost no new bone formation in the blank group. Quite a few new bones growing from defect margins were observed in the $\mathrm{O}-\mathrm{N}$ group, with limited newly formed bone in the centre. In the O-EMF group, extensive new bone formation was observed at the centre and periphery of the defect, indicating osseointegration of the new bone with the defect margins. The statistical results of BV/TV (Fig. 2b) and BMD (Fig. 2c) also support this argument. The sections stained with H\&E (Fig. 2d), Masson's trichrome (Fig. 2e), von Kossa (Fig. 2f) and the statistical analysis (Fig. 2g) revealed the same repair effects as the above tests. All experimental results indicated that 3D-printed scaffolds loaded with BMSCs treated by EMF accelerated bone regeneration.

\section{Osteogenic differentiation of BMSCs on scaffolds}

Osteogenesis is the crux of bone regeneration. Numerous tests have been conducted to explore the osteogenic differentiation of BMSCs stimulated by EMF. ALP is used as an early indicator of osteogenesis. Therefore, the cells cultured for 7 days were stained with ALP staining reagent and Direct Red 80. As shown in Fig. 3a, b, the cells from the O-EMF group were labeled with darkler colours, which represent higher expression levels of osteogenic indicators. When BMSCs were cultured in $\alpha$ MEM, EMF $(15 \mathrm{~Hz}, 0.3 \mathrm{mT})$ slightly increased ALP activity, collagen deposition and mineralization. These trends became more significant when BMSCs were cultured in OM. Consistent with the results of the above experiments, the expression of osteogenic genes (Fig. 4a) including bone morphogenetic protein 2 (BMP2), bone sialoprotein (BSP), runt-related gene 2 (Runx2), osteocalcin $(\mathrm{OCN})$ and osteopontin (OPN), also confirmed that BMSCs treated with EMF showed more significant osteogenic capacity under OM. Moreover, to further demonstrate the regulatory effect of EMF on BMSCs, western blotting was performed after 1 week of incubation to measure the expression levels of osteogenic proteins (Fig. 3c). All indicators, comprising BMP2, COL1 and $\mathrm{OCN}$, revealed that EMF did not directly induce osteogenic differentiation of BMSCs but promoted the osteogenic potential of cells, which would be fully realized under the induction of OM. The results of OPN, Runx2 and OCN immunofluorescence (Fig. 4a-c; Figure S1) also support this argument.

Regulatory effects of EMF on the BMP signalling pathway The key proteins in the BMP signalling pathway were investigated to further explain the regulation of BMSCs by EMF. According to the experimental results (Fig. 5b), EMF significantly upregulated the gene expression of BMP receptors, including BMPR1A, BMPR1B and BMPR2, while ACVR1 did not seem to be affected by EMF. For Smad4 and Smad1/5/8, which are downstream 


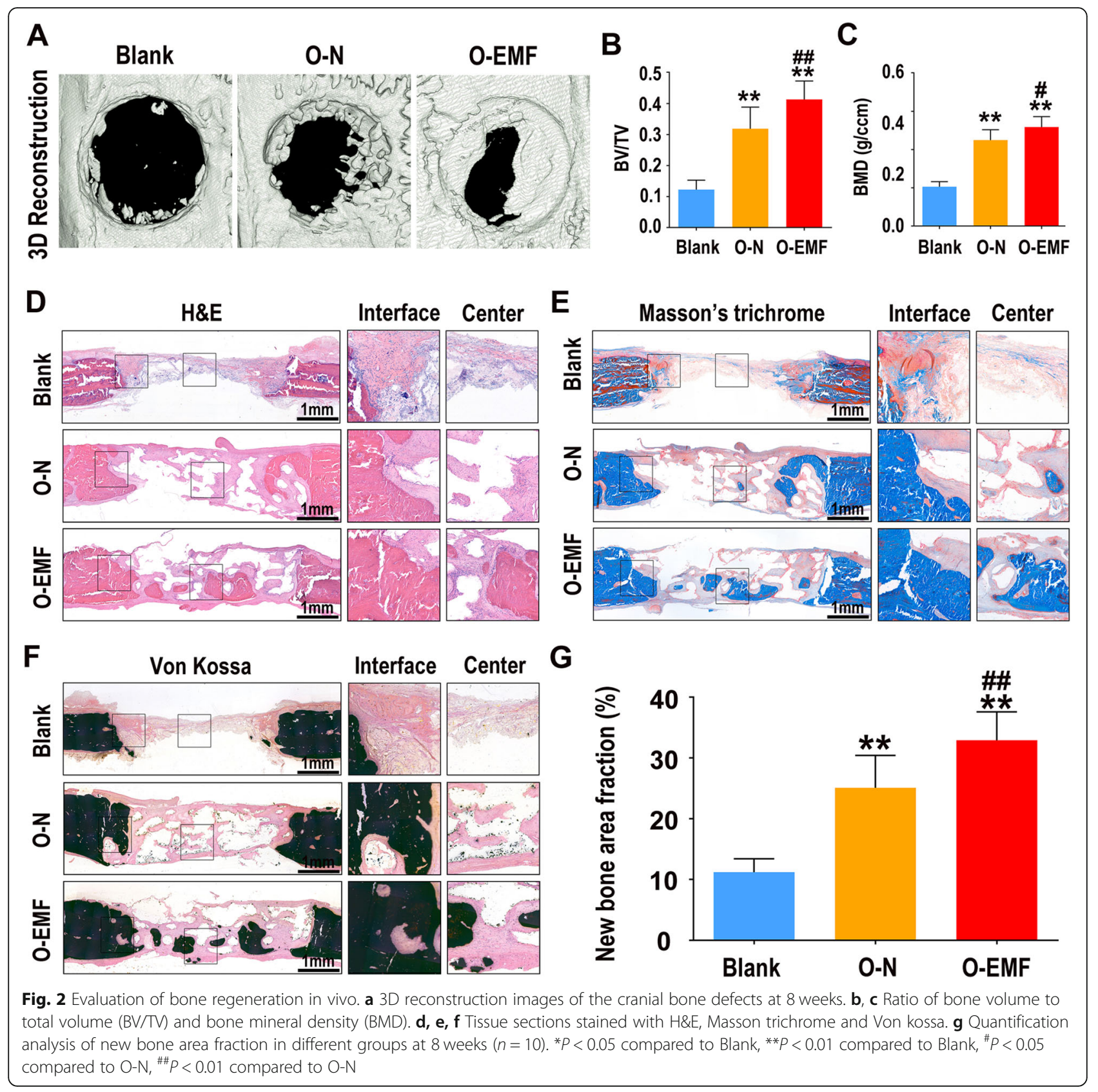

of these receptors, upregulated genes were detected when BMSCs treated with EMF were cultured in OM. As expected, the effect of EMF on the Smad-dependent BMP pathway was significantly weakened with the participation of LDN193189. In addition, the immunofluorescence results of P-Smad1/5/8, BMPR1B and BMPR2 were similar to those of the PCR assay (Fig. 5a; Figure S2).

\section{Pro-angiogenic capacity of BMSCs treated by EMF}

According to the detection of angiogenic genes of EPCs assigned to three groups, it was clear that conditioned media promoted the angiogenesis of EPCs, and the angiogenic genes in the O-EMF group were upregulated almost twofold compared with those in the O-N group (Fig. 6c). At the same time, the conditioned media accelerated the formation of capillary-like structures in Matrigel during the $6 \mathrm{~h}$ of incubation. Both intuitive evaluation (Fig. 6a) and statistical data (Fig. 6b) suggested that conditioned medium of the O-EMF group exerted a more prominent effect in terms of promoting angiogenesis.

Osteoimmunomodulation of BMSCs treated by EMF Macrophages have an irreplaceable role in osteoimmunomodulation, which is a pivotal process in bone 


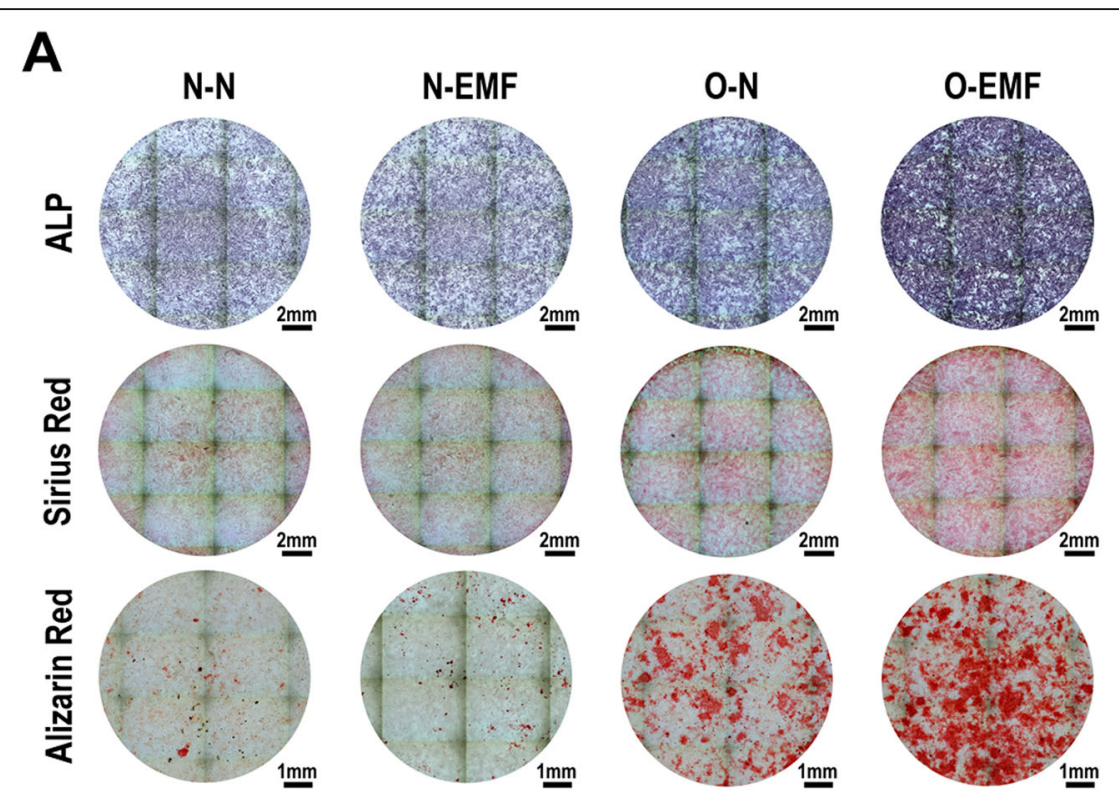

B

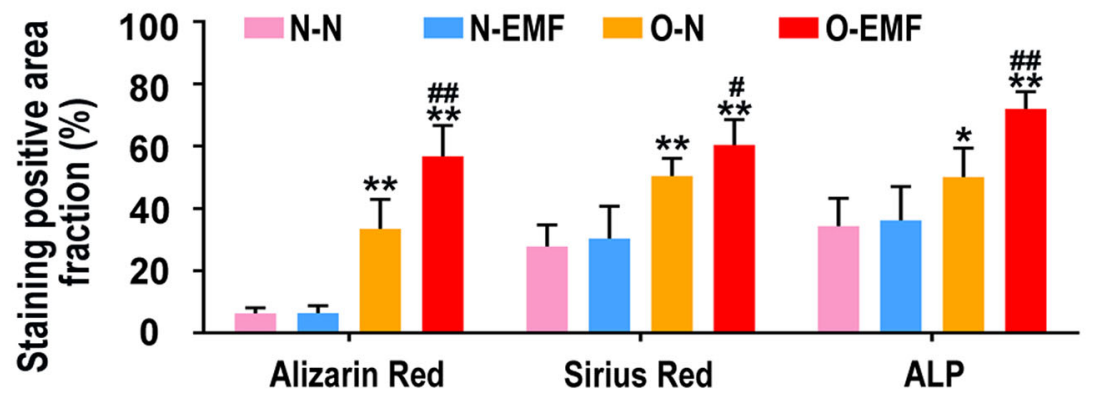

C
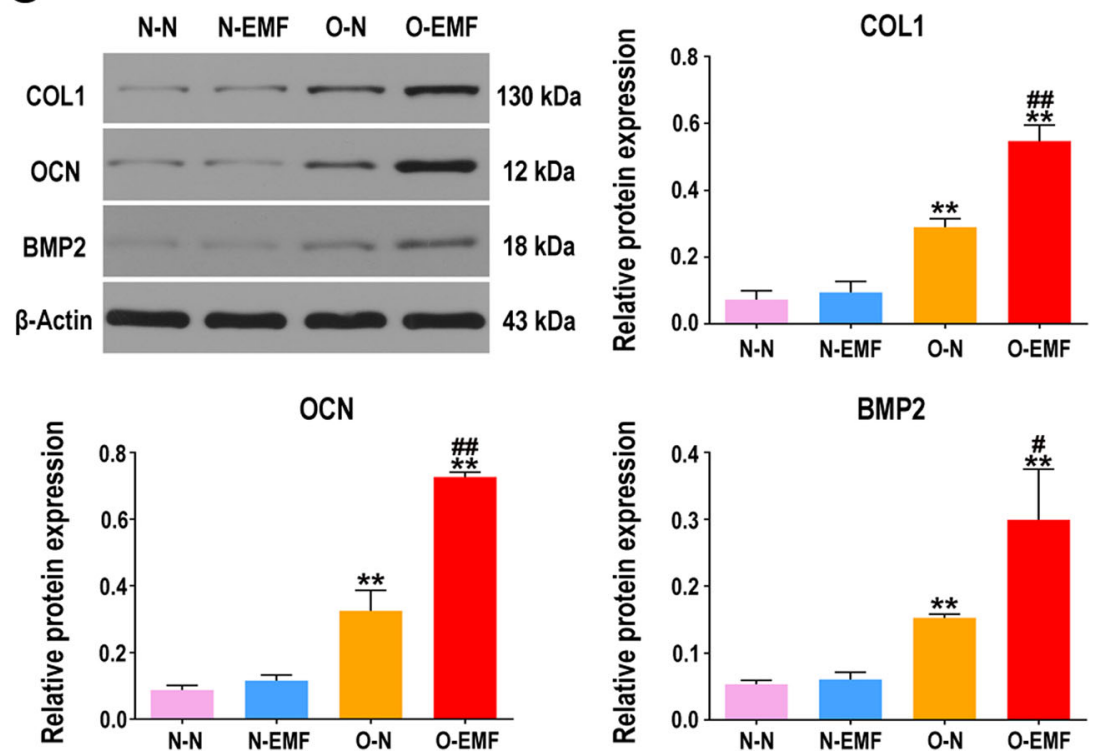

Fig. 3 (See legend on next page.) 
(See figure on previous page.)

Fig. 3 Regulation of EMF on osteogenic differentiation of BMSCs. a Images of ALP, Sirius Red and Alizarin Red staining of BMSCs seeded in 24well plates after culturing for 1 week. $\mathbf{b}$ Semi-quantitative analysis of ALP, Sirius Red and Alizarin Red staining among both groups $(n=6)$. Data shown as mean \pm SD. $\mathbf{c}$ Effects of EMF on osteogenic protein expression of BMSCs seeded on scaffolds after culturing for 1 weeks (COL1, OCN and BMP2) detected by western blotting. ${ }^{*} P<0.05$ compared to $\mathrm{N}-\mathrm{N}$, ${ }^{* *} P<0.01$ compared to $\mathrm{N}-\mathrm{N}$, ${ }^{\#} P<0.05$ compared to $0-\mathrm{N}$, ${ }^{\# \#} P<0.01$ compared to O-N

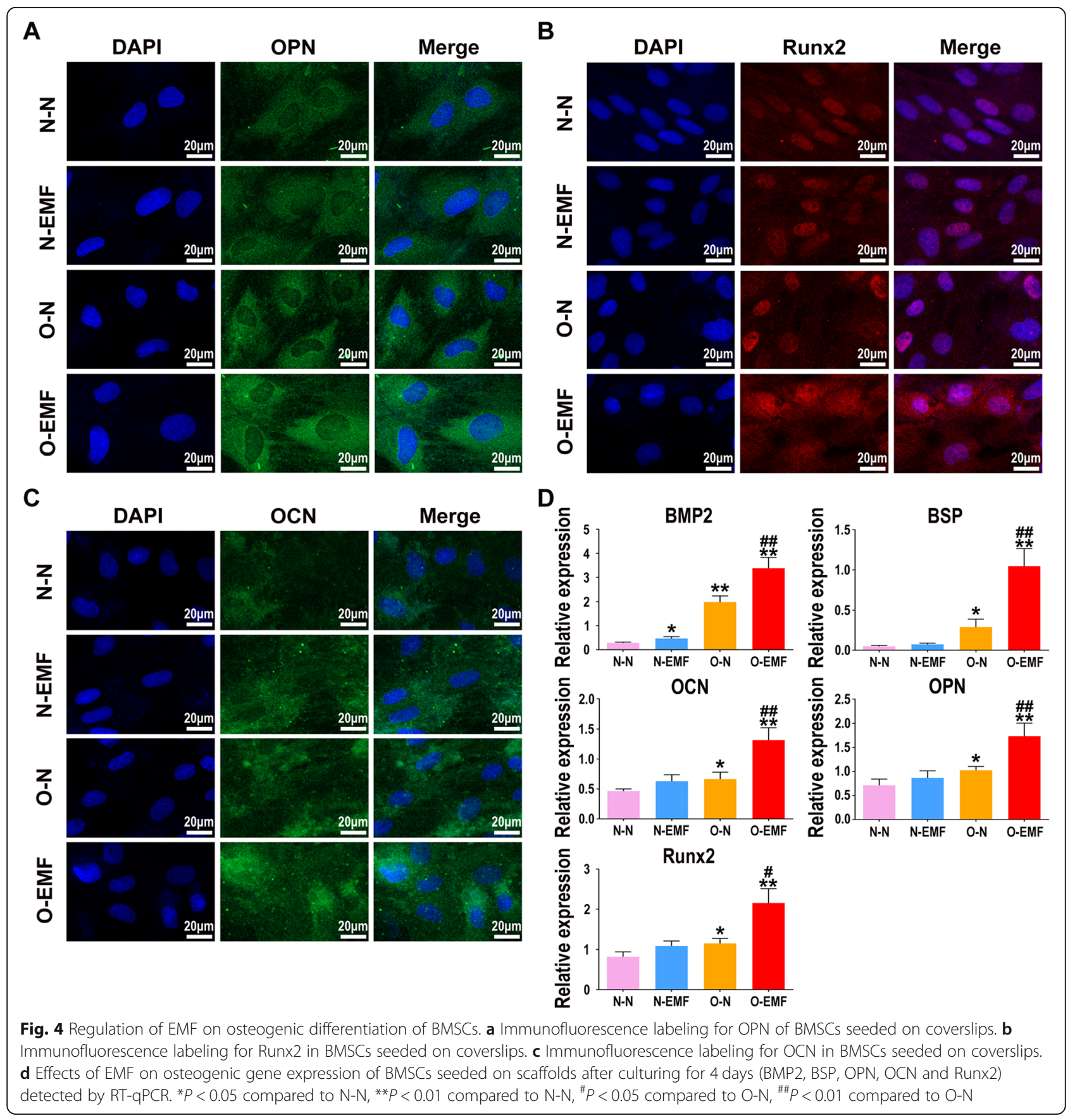




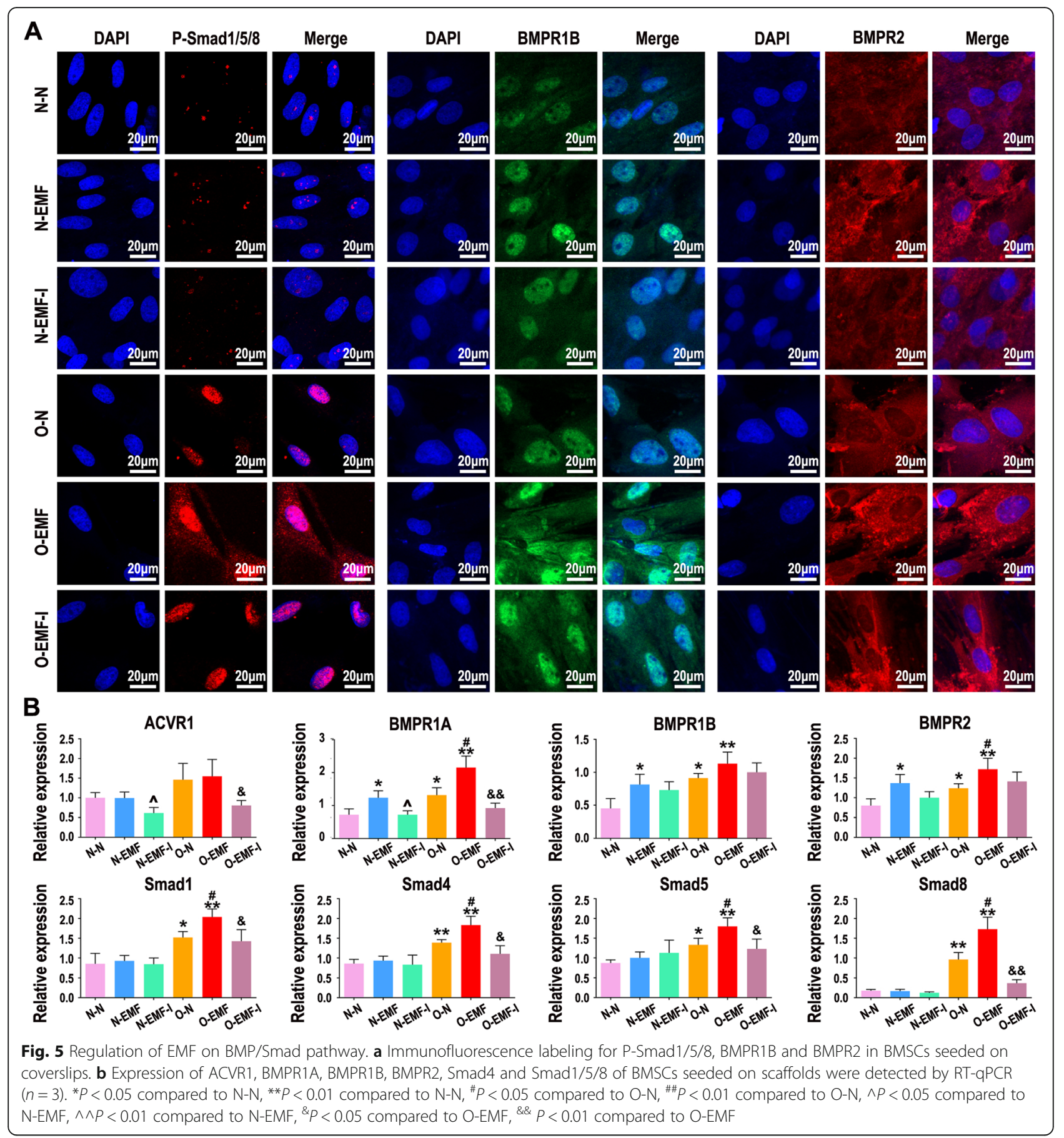

regeneration. After implantation, macrophages swiftly migrate to the interface between the graft and bone and manipulate the surrounding immune microenvironment in response to changes in the living environment [43]. The gene expressions of RAW cells cultured in conditioned media was evaluated by RT-qPCR. Compared to the blank group, the expression of genes associated with the proinflammatory M1 phenotype, such as IL-1 and IL-6, was significantly increased in the control group
(Fig. 7b). This result indicated that we successfully simulated the early inflammatory environment at the fracture site. In the meantime, conditioned media downregulated the expression of proinflammatory genes, and the conditioned medium of the O-EMF group seemed to be more effective in terms of inhibiting inflammation. In addition, the expression of genes related to the pro-healing M2 phenotype in the O-EMF group was significantly higher than that in the control and O-N groups (Fig. 7a). The 


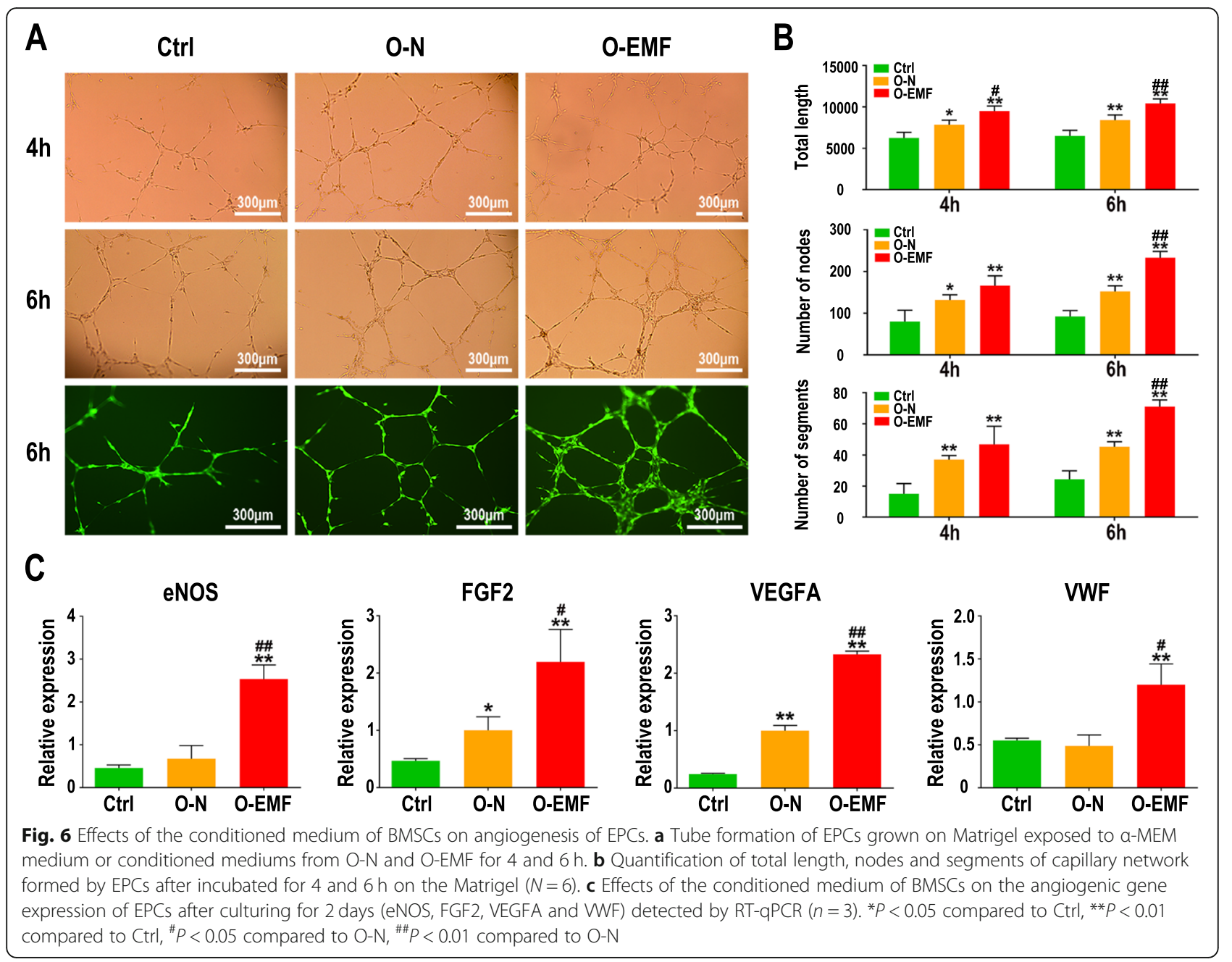

results of flow cytometry (Fig. 7c-e) were almost the same as those of RT-qPCR. RAW cells cultured with the conditioned media showed a clear tendency to differentiate to the M2 phenotype, and the conditioned medium of the O-EMF group was more effective at promoting the M2 phenotype over the M1 phenotype.

\section{Discussion}

Seeded cells, cytokines and cellular biological scaffolds are crucial elements of bone tissue engineering $[44,45]$. In recent decades, much attention has been given to BMSCs and their use for bone tissue engineering. Therefore, we believe that improving the multifunctionality of BMSCs is significant for accelerating the repair of bone defects. Our previous work demonstrated that sinusoidal EMF is a convenient and economical method to promote osteogenesis in BMSCs $[24,46]$. Therefore, after many attempts, electromagnetic fields with specific parameters $(15 \mathrm{~Hz}, 0.3$ $\mathrm{mT}$ ) were selected to modulate the pluripotency of BMSCs. At the same time, PCL/HA scaffolds coated with polydopamine were manufactured as cell vehicles.
In in vitro experiments, the expression of osteogenic genes (BMP2, BSP, OCN, OPN, Runx2) and osteogenic proteins (COL1, OCN, BMP2) and the staining of osteogenic markers (ALP, collagen, mineralization) indicated that EMF significantly improved the osteogenic ability of BMSCs cultured in OM. Nevertheless, it is worth considering that when BMSCs were cultured in normal medium, the effect of EMF on cells seemed to disappear. To clearly explain this strange phenomenon, we need to understand the mechanism by which EMF affects BMSCs.

TGF- $\beta$ and BMP signalling play a fundamental role in embryonic bone development and postpartum bone homeostasis [47]. They regulate the differentiation of BMSCs by acting on the tetrameric receptor complex to trigger a cascade reaction downstream of the pathway. Many human bone diseases are attributed to the dysregulation of TGF- $\beta$ and BMP signalling [48]. Therefore, we hypothesized that EMF affects the osteogenic differentiation of BMSCs by regulating the BMP signalling pathway. As a member of the TGF- $\beta$ superfamily, BMP works by binding to type I and type II BMP receptors on the cell 


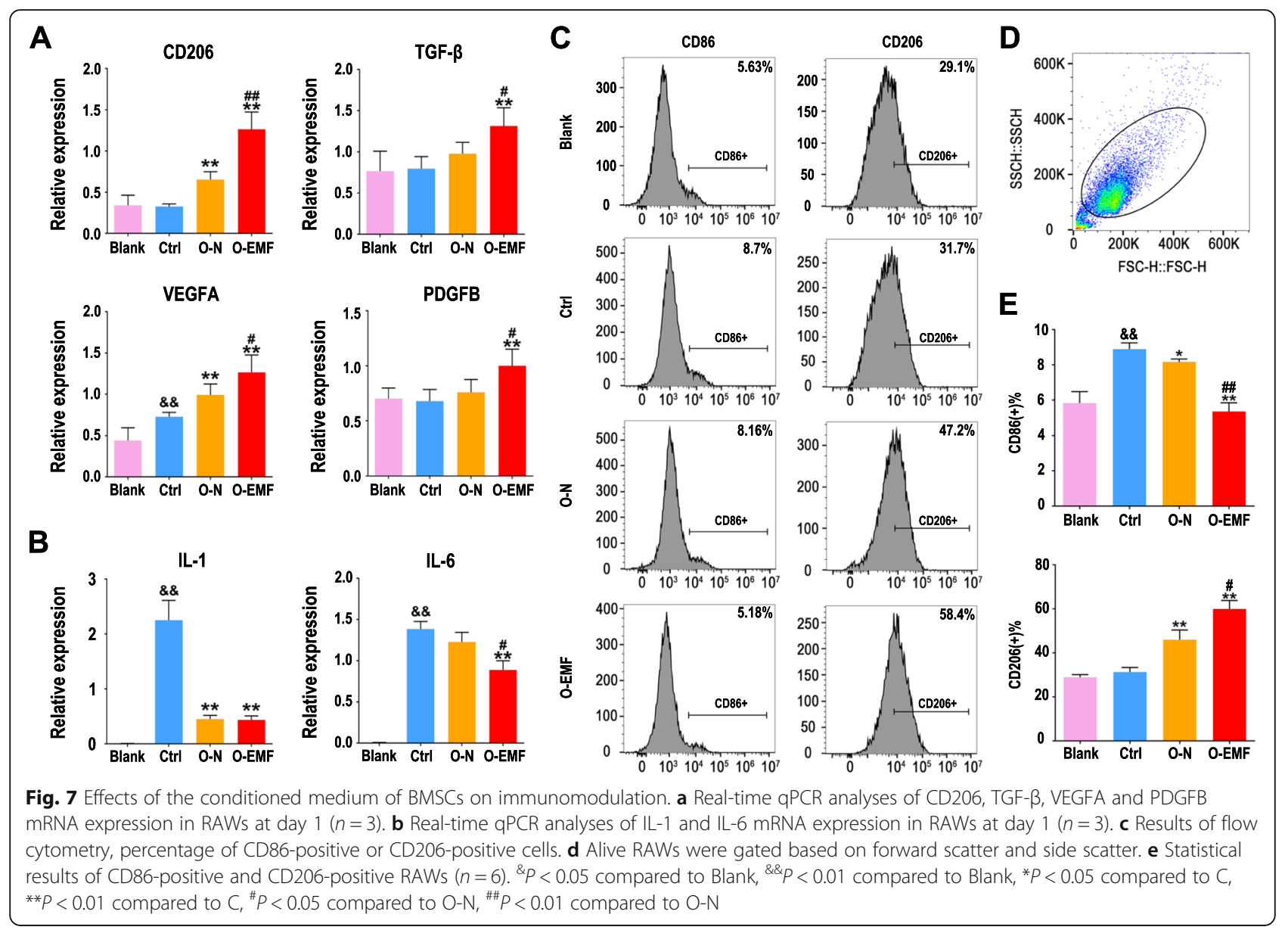

surface. After binding to the BMP ligand, the homodimer of the type II receptor and the homodimer of the type I receptor form a tetramer complex, which induces the transphosphorylation of the type I receptor $[48,49]$. The phosphorylated type I receptor binds to Smad1/5/8 and enters the nucleus under the guidance of Smad4, where these proteins recruit cofactors and Runx2 to regulate the expression of osteogenic genes. In subsequent experiments, we found that EMF can upregulate the gene expression of BMPR1A, BMPR1B, BMPR2, Smad4 and Smad1/5/8 in BMSCs cultured with OM. The regulation of BMSCs by EMF was weakened with the participation of a BMP type I receptor inhibitor. These results confirmed our conjecture that EMF regulates the osteogenic differentiation of BMSCs through the BMP signalling pathway. However, in the absence of OM, EMF upregulated the expression of specific BMP receptors but did not enhance the expression of osteogenic indicators such as OPN, $\mathrm{OCN}$ and Runx2. This result suggested that the BMP/ Smad signalling pathway was not fully activated. Therefore, we speculated that EMF could not induce the osteogenic differentiation of BMSCs directly but promoted their osteogenic potential by upregulating the quantity of specific BMP receptors. Although the increased receptor expression help cells receive extrinsic BMP signals, they cannot phosphorylate downstream components. Once these induced cells receive BMP signals from the surrounding milieu, the transmembrane receptors will bind to the signals to trigger cascade reactions through the $\mathrm{BMP} /$ Smad pathway. At this moment, the osteogenic potential of the stem cells is fully realized.

We also found that BMSCs stimulated by EMF contribute to the angiogenesis of EPCs. As a prosurvival factor of endothelial cells (ECs) both in vitro and in vivo, VEGF plays an indispensable role in the process of angiogenesis [50, 51]. VEGF binds to its corresponding receptor, VEGFR, and induces its homodimerization, which activates eNOS to realize the production of vascular nitric oxide (NO) [52]. The diffusion of NO in the vasculature not only contributes to vascular permeability but also promotes the proliferation and migration of ECs [53]. It has been reported that BMSCs can secrete angiogenic factors such as VEGF and erythropoietin [54]. This reasonably explains why the conditioned media of BMSCs enhanced the angiogenic ability of EPCs. Nevertheless, both tube formation assays and RTqPCR experiments showed that the conditioned medium of 
BMSCs stimulated by EMF further increased the expression of angiogenic genes in EPCs. This may be attributed to EMF boosting the secretion of angiogenic factors by BMSCs. Thus, a scaffold loaded with BMSCs induced by EMF implanted into a bone defect may be more conducive to the angiogenesis of surrounding endothelial cells. FGF expressed in ECs acts together with Runx2 to promote the proliferation of osteoblasts and the execution of the osteogenic programme [55].

The effects of EMF on stem cells go far beyond the process described above. BMSCs stimulated by EMF positively regulate the immune microenvironment. Once bone defects occur, numerous macrophages gather around the wound and show considerable plasticity according to signals derived from the surrounding environment [43]. The M1 and M2 phenotypes represent two extremes of macrophage polarization [56]. In acute inflammation, M1 macrophages play a major role by promoting the migration of BMSCs and clearing cell debris and bacterial pathogens $[57,58]$. However, the activated M1 phenotype stimulates inflammation by producing CD86 and iNOS (nitric oxide synthases), which are not conducive to bone regeneration. In contrast, the activated M2 phenotype inhibits inflammation and promotes healing by secreting CD206 and IL-10. According to our experimental results, BMSCs promoted macrophages to differentiate towards an M2-like phenotype, which is consistent with the results of previous studies [59, 60]. Moreover, BMSCs stimulated by EMF not only further promoted the polarization of RAW cells towards the M2 phenotype, which benefits tissue regeneration, but also inhibited the inflammatory response. Upregulated genes, such as TGF- $\beta$, are transcribed and translated and act on BMSCs through the paracrine pathway to inhibit osteoclast differentiation, thereby contributing to osteogenesis $[61,62]$. These pathways that mediate osteogenic differentiation have been verified many times in previous reports and in our research, which further illustrated that EMF promoted the osteogenic potential of BMSCs and boosted the paracrine function of BMSCs to facilitate angiogenesis and osteoimmunomodulation (Fig. 8).

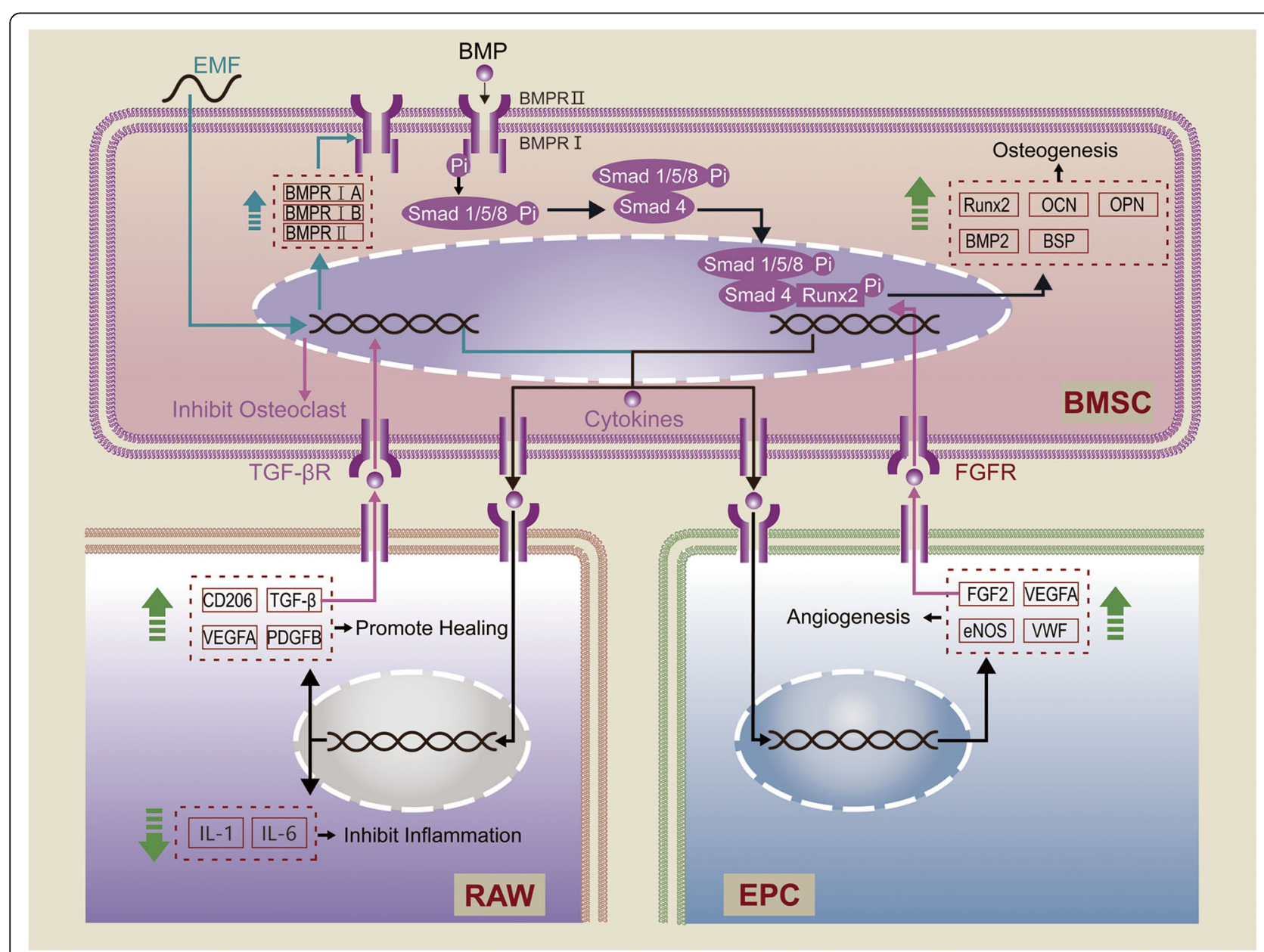

Fig. 8 Explanation of the mechanism by which EMF motivates the multiple potential of BMSCs to facilitate osteogenesis, angiogenesis and osteoimmunomodulation 
In the in vivo experiments, the repair of cranial defects was not perfect. This result may be related to the inadequate time for animal rearing caused by COVID-19. The fact that there was little new bone formation in the blank group indicated that critical-sized bone defects were difficult to self-heal and that it is necessary to involve biomaterials in treatment. The PCL/HA scaffolds with polydopamine surface modification demonstrated desirable osteoconductive and osseointegration properties during bone repair. However, stem cells on scaffolds can better promote osteogenesis in vivo with the assistance of EMF. In general, EMF can promote multifunctionality of BMSCs to contribute to bone regeneration. The technology of individualized 3D printing ensures anastomosis between scaffolds and defect sites. Advanced materials possess ideal osteoconductive and osseointegration capabilities. Combining the advantages of different technologies to generate a new treatment system is of great significance for clinical treatment.

\section{Conclusions}

In summary, BMSCs stimulated by EMF $(15 \mathrm{~Hz}, 0.3 \mathrm{mT})$ improve sensitivity to BMP signals by upregulating the quantity of specific BMP receptors. Cascade reactions will be initiated to promote osteogenic differentiation once these stimulated cells receive BMP signals from the surrounding milieu. Furthermore, EMF enhances the paracrine function of BMSCs to facilitate angiogenesis and osteoimmunomodulation. It has been confirmed that the effect of EMF on bone regeneration involves a comprehensive and complex process. The combination of EMF and tissue engineering techniques optimizes the regeneration ability of BMSCs while avoiding the adverse effects of EMF. Our research highlights the profound impact of EMF on tissue engineering and provides an effective strategy for EMF clinical treatment of bone defects.

\section{Abbreviations}

EMFs: Electromagnetic fields; PCL: Polycaprolactone; HA: Hydroxyapatite; BMSCs: Bone marrow mesenchymal stem cells; BTE: Bone tissue engineering; OM: Osteogenic medium; FDM: Fused deposition modeling; FBS: Foetal bovine serum; PBS: Phosphate-buffered saline; SEM: Scanning electron microscopy; CT: Computed tomography; HE: Haematoxylin and eosin; BV: Bone volume; TV: Total volume; BMD: Bone mineral density; ALP: Alkaline phosphatase; BMP2: Bone morphogenetic protein 2; OPN: Osteopontin; BMPR1B: Type IB BMP receptor; BSA: Bone serum albumin; Runx2: Runtrelated gene 2; COL1: Type 1 collagen; BMPR1A: Type IA BMP receptor; BMPR1B: Type IB BMP receptor; BMPR2: Type II BMP receptor; ACVR1: Type I activin receptor

\section{Supplementary Information}

Supplementary information accompanies this paper at https://doi.org/10. 1186/s13287-021-02302-Z

Additional file 1: Figure S1. Fluorescence quantitative analysis of OPN, OCN and Runx2 $(n=6) .{ }^{*} P<0.05$ compared to N-N, ${ }^{* *} P<0.01$ compared to $\mathrm{N}-\mathrm{N},{ }^{\#} \mathrm{P}<0.05$ compared to O-N, ${ }^{\# \#} \mathrm{P}<0.01$ compared to O-N.
Additional file 2: Figure S2. Fluorescence quantitative analysis of BMPR1B, BMPR2 and P-Smad1/5/8 $(n=6)$. ${ }^{*} \mathrm{P}<0.05$ compared to N-N, ** $\mathrm{P}<0.01$ compared to $\mathrm{N}-\mathrm{N}$, ${ }^{*} \mathrm{P}<0.05$ compared to $\mathrm{O}-\mathrm{N}$, \#\# $\mathrm{P}<0.01 \mathrm{com}-$ pared to O-N, $\wedge \mathrm{P}<0.05$ compared to $\mathrm{N}-\mathrm{EMF}, \wedge \wedge \mathrm{P}<0.01$ compared to $\mathrm{N}-\mathrm{EMF},{ }^{\&} \mathrm{P}<0.05$ compared to $\mathrm{O}-\mathrm{EMF},{ }^{\& \&} \mathrm{P}<0.01$ compared to O-EMF.

\section{Acknowledgements}

Not applicable.

\section{Authors' contributions}

WL: Conception and design, provision of study material or patients, collection and/or assembly of data, data analysis and interpretation, manuscript writing, final approval of manuscript. WL: Conception and design, provision of study material or patients, collection and/or assembly of data, data analysis and interpretation, manuscript writing, final approval of manuscript. WW: provision of study material or patients, collection and/or assembly of data. JW: provision of study material or patients, collection and/ or assembly of data. TM: provision of study material or patients. JC: provision of study material or patients. HW: Conception and design, financial support, administrative support, final approval of manuscript. CL: Conception and design, financial support, final approval of manuscript. The author(s) read and approved the final manuscript.

\section{Funding}

This study was supported by the National Natural Science Foundation of China (grant nos. 51537004, 51877097).

\section{Availability of data and materials}

The datasets used and/or analysed during the current study are available from the corresponding author on reasonable request.

\section{Declarations}

Ethics approval and consent to participate

All animal experimental procedures were complying with the Guidelines of Animal Care and Use Committee for Teaching and Research of Huazhong University of Science and Technology. The experimental protocol was approved by the committee. All efforts were conducted to minimize animal suffering.

\section{Consent for publication}

Not applicable.

\section{Competing interests}

The authors have no financial disclosures or conflict of interest with the research presented here.

\section{Author details}

${ }^{1}$ Department of Orthopedics, Tongji Hospital, Tongji Medical College, Huazhong University of Science and Technology, Wuhan 430030, Hubei, China. ${ }^{2}$ Department of Orthopedics, Xiangya Hospital of Central South University, Changsha 410008, Hunan, China. ${ }^{3}$ Department of Hematology, Tongji Hospital, Tongji Medical College, Huazhong University of Science and Technology, Wuhan 430030, Hubei, China. ${ }^{4}$ Department of Cardiothoracic Surgery, Tongji Hospital, Tongji Medical College, Huazhong University of Science and Technology, Wuhan 430030, Hubei, China.

Received: 29 January 2021 Accepted: 22 March 2021

Published online: 13 April 2021

\section{References}

1. Bosco J, lorio R, Barber T, Barron C, Caplan A. Ethics of the physician's role in health-care cost control: AOA critical issues. J Bone Joint Surg Am. 2016; 98(14):e58. https://doi.org/10.2106/JBJS.15.00889.

2. Tarride JE, Guo N, Hopkins R, Leslie WD, Morin S, Adachi JD, Papaioannou A, Bessette L, Brown JP, Goeree R. The burden of illness of osteoporosis in Canadian men. J Bone Miner Res. 2012;27(8):1830-8. https://doi.org/10.1002/ jbmr.1615. 
3. Bosco JA 3rd, Karkenny AJ, Hutzler LH, Slover JD, lorio R. Cost burden of 30day readmissions following Medicare total hip and knee arthroplasty. J Arthroplast. 2014;29(5):903-5. https://doi.org/10.1016/j.arth.2013.11.006.

4. Wang W, Yeung KWK. Bone grafts and biomaterials substitutes for bone defect repair: a review. Bioact Mater. 2017;2(4):224-47. https://doi.org/10.101 6/j.bioactmat.2017.05.007.

5. Keating JF, Simpson AH, Robinson CM. The management of fractures with bone loss. J Bone Joint Surg Br. 2005;87(2):142-50.

6. Garcia-Gareta E, Coathup MJ, Blunn GW. Osteoinduction of bone grafting materials for bone repair and regeneration. Bone. 2015;81:112-21. https:// doi.org/10.1016/j.bone.2015.07.007.

7. Zhang J, Liu W, Schnitzler V, Tancret F, Bouler JM. Calcium phosphate cements for bone substitution: chemistry, handling and mechanical properties. Acta Biomater. 2014;10(3):1035-49. https://doi.org/10.1016/j.a ctbio.2013.11.001.

8. Perez JR, Kouroupis D, Li DJ, Best TM, Kaplan L, Correa D. Tissue engineering and cell-based therapies for fractures and bone defects. Front Bioeng Biotechnol. 2018;6:105. https://doi.org/10.3389/fbioe.2018.00105.

9. Polymeri A, Giannobile WV, Kaigler D. Bone marrow stromal stem cells in tissue engineering and regenerative medicine. Horm Metab Res. 2016; 48(11):700-13.

10. Baksh D, Boland GM, Tuan RS. Cross-talk between Wht signaling pathways in human mesenchymal stem cells leads to functional antagonism during osteogenic differentiation. J Cell Biochem. 2007;101(5):1109-24. https://doi. org/10.1002/jcb.21097.

11. Motegi SI, Ishikawa O. Mesenchymal stem cells: the roles and functions in cutaneous wound healing and tumor growth. J Dermatol Sci. 2017;86(2):839. https://doi.org/10.1016/j.jdermsci.2016.11.005.

12. Wang J, Wang Y, Wang S, Cai J, Shi J, Sui X, Cao Y, Huang W, Chen X, Cai Z, Li H, Bardeesi ASA, Zhang B, Liu M, Song W, Wang M, Xiang AP. Bone marrow-derived mesenchymal stem cell-secreted IL-8 promotes the angiogenesis and growth of colorectal cancer. Oncotarget. 2015;6(40): 42825-37. https://doi.org/10.18632/oncotarget.5739.

13. Shou K, Niu Y, Zheng X, Ma Z, Jian C, Qi B, et al. Enhancement of bonemarrow-derived mesenchymal stem cell angiogenic capacity by NPWT for a combinatorial therapy to promote wound healing with large defect. Biomed Res Int. 2017;2017:7920265.

14. He Y, Chen D, Yang L, Hou Q, Ma H, Xu X. The therapeutic potential of bone marrow mesenchymal stem cells in premature ovarian failure. Stem Cell Res Ther. 2018;9(1):263. https://doi.org/10.1186/s13287-018-1008-9.

15. Bassett CA, Pawluk RJ, Pilla AA. Acceleration of fracture repair by electromagnetic fields. A surgically noninvasive method. Ann N Y Acad Sci. 1974;238(1 Electrically):242-62. https://doi.org/10.1111/j.1749-6632.1974.tb2 6794.x.

16. Pilla AA. Nonthermal electromagnetic fields: from first messenger to therapeutic applications. Electromagn Biol Med. 2013;32(2):123-36. https:// doi.org/10.3109/15368378.2013.776335.

17. Ross CL, Syed I, Smith TL, Harrison BS. The regenerative effects of electromagnetic field on spinal cord injury. Electromagn Biol Med. 2017; 36(1):74-87.

18. Kumar S, Dey S, Jain S. Extremely low-frequency electromagnetic fields: a possible non-invasive therapeutic tool for spinal cord injury rehabilitation. Electromagn Biol Med. 2017;36(1):88-101.

19. Belyaev I, Dean A, Eger H, Hubmann G, Jandrisovits R, Kern M, et al. EUROPAEM EMF Guideline 2016 for the prevention, diagnosis and treatment of EMF-related health problems and illnesses. Rev Environ Health. 2016;31(3):363-97.

20. Kocaman A, Altun G, Kaplan AA, Deniz OG, Yurt KK, Kaplan S. Genotoxic and carcinogenic effects of non-ionizing electromagnetic fields. Environ Res. 2018;163:71-9. https://doi.org/10.1016/j.envres.2018.01.034.

21. Terzi M, Ozberk B, Deniz OG, Kaplan S. The role of electromagnetic fields in neurological disorders. J Chem Neuroanat. 2016;75(Pt B):77-84.

22. Destefanis M, Viano M, Leo C, Gervino G, Ponzetto A, Silvagno F. Extremely low frequency electromagnetic fields affect proliferation and mitochondrial activity of human cancer cell lines. Int J Radiat Biol. 2015;91(12):964-72. https://doi.org/10.3109/09553002.2015.1101648.

23. Tu C, Chen J, Huang C, Xiao Y, Tang X, Li H, Ma Y, Yan J, Li W, Wu $H$, Liu C. Effects of electromagnetic fields treatment on rat criticalsized calvarial defects with a 3D-printed composite scaffold. Stem Cell Res Ther. 2020;11(1):433. https://doi.org/10.1186/s13287-020-01 954-7.
24. Chen J, Tu C, Tang X, Li H, Yan J, Ma Y, Wu H, Liu C. The combinatory effect of sinusoidal electromagnetic field and VEGF promotes osteogenesis and angiogenesis of mesenchymal stem cell-laden PCL/HA implants in a rat subcritical cranial defect. Stem Cell Res Ther. 2019;10(1):379. https://doi. org/10.1186/s13287-019-1464-x.

25. Li W, Huang C, Ma T, Wang J, Liu W, Yan J, Sheng G, Zhang R, Wu H, Liu C. Low-frequency electromagnetic fields combined with tissue engineering techniques accelerate intervertebral fusion. Stem Cell Res Ther. 2021;12(1): 143. https://doi.org/10.1186/s13287-021-02207-x.

26. Domingos M, Gloria A, Coelho J, Bartolo P, Ciurana J. Three-dimensional printed bone scaffolds: the role of nano/micro-hydroxyapatite particles on the adhesion and differentiation of human mesenchymal stem cells. Proc Inst Mech Eng H. 2017;231(6):555-64. https://doi.org/10.1177/095441191 6680236.

27. Venugopal J, Rajeswari R, Shayanti M, Low S, Bongso A, Dev VR, et al. Electrosprayed hydroxyapatite on polymer nanofibers to differentiate mesenchymal stem cells to osteogenesis. J Biomater Sci Polym Ed. 2013; 24(2):170-84. https://doi.org/10.1163/156856212X629845.

28. Ge L, Li Q, Huang Y, Yang S, Ouyang J, Bu S, Zhong W, Liu Z, Xing MMQ. Polydopamine-coated paper-stack nanofibrous membranes enhancing adipose stem cells' adhesion and osteogenic differentiation. J Mater Chem B. 2014;2(40):6917-23. https://doi.org/10.1039/C4TB00570H.

29. Wang J, Chen Y, Zhou G, Chen Y, Mao C, Yang M. Polydopamine-coated Antheraea pernyi (a. pernyi) silk fibroin films promote cell adhesion and wound healing in skin tissue repair. ACS Appl Mater Interfaces. 2019;11(38): 34736-43. https://doi.org/10.1021/acsami.9b12643.

30. Lee $H$, Dellatore SM, Miller WM, Messersmith PB. Mussel-inspired surface chemistry for multifunctional coatings. Science. 2007;318(5849):426-30. https://doi.org/10.1126/science.1147241

31. Zhang Y, Yan J, Xu H, Yang Y, Li W, Wu H, Liu C. Extremely low frequency electromagnetic fields promote mesenchymal stem cell migration by increasing intracellular $\mathrm{ca}(2+)$ and activating the FAK/rho GTPases signaling pathways in vitro. Stem Cell Res Ther. 2018;9(1):143. https:/doi.org/10.1186/ s13287-018-0883-4.

32. Zhang Y, Li W, Liu C, Yan J, Yuan X, Wang W, Wang H, Wu H, Yang Y. Electromagnetic field treatment increases purinergic receptor $\mathrm{P} 2 \mathrm{X} 7$ expression and activates its downstream Akt/GSK3beta/beta-catenin axis in mesenchymal stem cells under osteogenic induction. Stem Cell Res Ther. 2019;10(1):407. https://doi.org/10.1186/s13287-019-1497-1.

33. Yao Q, Cosme JG, Xu T, Miszuk JM, Picciani PH, Fong H, et al. Three dimensional electrospun PCL/PLA blend nanofibrous scaffolds with significantly improved stem cells osteogenic differentiation and cranial bone formation. Biomaterials. 2017;115:115-27. https://doi.org/10.1016/j. biomaterials.2016.11.018

34. Ampuja M, Kallioniemi A. Transcription factors-intricate players of the bone morphogenetic protein signaling pathway. Genes Chromosomes Cancer. 2018;57(1):3-11. https://doi.org/10.1002/gcc.22502.

35. Niehrs C. On growth and form: a Cartesian coordinate system of Wnt and BMP signaling specifies bilaterian body axes. Development. 2010;137(6):84557. https://doi.org/10.1242/dev.039651.

36. Katagiri T, Watabe T. Bone morphogenetic proteins. Cold Spring Harb Perspect Biol. 2016;8(6):a021899. https://doi.org/10.1101/cshperspect.a021 899.

37. Kumar Y, Biswas T, Thacker G, Kanaujiya JK, Kumar S, Shukla A, Khan K, Sanyal S, Chattopadhyay N, Bandyopadhyay A, Trivedi AK. BMP signalingdriven osteogenesis is critically dependent on Prdx-1 expression-mediated maintenance of chondrocyte prehypetrophy. Free Radic Biol Med. 2018;118: 1-12. https://doi.org/10.1016/j.freeradbiomed.2018.02.016.

38. Tang Y, Wu X, Lei W, Pang L, Wan C, Shi Z, Zhao L, Nagy TR, Peng X, Hu J, Feng $X$, van Hul W, Wan M, Cao X. TGF-beta1-induced migration of bone mesenchymal stem cells couples bone resorption with formation. Nat Med. 2009;15(7):757-65. https://doi.org/10.1038/nm.1979.

39. Crane $J$, Xian L, Cao X. Role of TGF-beta signaling in coupling bone remodeling. Methods Mol Biol. 2016;1344:287-300. https://doi.org/10.1007/ 978-1-4939-2966-5_18.

40. Spiller KL, Anfang RR, Spiller KJ, Ng J, Nakazawa KR, Daulton JW, VunjakNovakovic $\mathrm{G}$. The role of macrophage phenotype in vascularization of tissue engineering scaffolds. Biomaterials. 2014;35(15):4477-88. https://doi.org/10.1 016/j.biomaterials.2014.02.012.

41. Ciapetti G, Ambrosio L, Savarino L, Granchi D, Cenni E, Baldini N, Pagani S, Guizzardi S, Causa F, Giunti A. Osteoblast growth and function in porous 
poly epsilon -caprolactone matrices for bone repair: a preliminary study. Biomaterials. 2003;24(21):3815-24. https://doi.org/10.1016/S0142-9612(03 )00263-1.

42. Wang $H$, Lin C, Zhang $X$, Lin K, Wang $X$, Shen SG. Mussel-inspired Polydopamine coating: a general strategy to enhance Osteogenic differentiation and Osseointegration for diverse implants. ACS Appl Mater Interfaces. 2019;11(7):7615-25. https://doi.org/10.1021/acsami.8b21 558.

43. Bai L, Du Z, Du J, Yao W, Zhang J, Weng Z, et al. A multifaceted coating on titanium dictates osteoimmunomodulation and osteo/angio-genesis towards ameliorative osseointegration. Biomaterials. 2018;162:154-69. https://doi.org/10.1016/j.biomaterials.2018.02.010.

44. Shi R, Huang Y, Ma C, Wu C, Tian W. Current advances for bone regeneration based on tissue engineering strategies. Front Med. 2019;13(2): 160-88. https://doi.org/10.1007/s11684-018-0629-9.

45. Zhang PX, Han N, Kou YH, Zhu QT, Liu XL, Quan DP, et al. Tissue engineering for the repair of peripheral nerve injury. Neural Regen Res. 2019;14(1):51-8.

46. Tu C, Xiao Y, Ma Y, Wu H, Song M. The legacy effects of electromagnetic fields on bone marrow mesenchymal stem cell self-renewal and multiple differentiation potential. Stem Cell Res Ther. 2018;9(1):215. https://doi.org/1 0.1186/s13287-018-0955-5.

47. Luo K. Signaling cross talk between TGF-beta/Smad and other signaling pathways. Cold Spring Harb Perspect Biol. 2017;9(1):a022137. https://doi. org/10.1101/cshperspect.a022137

48. Wu M, Chen G, Li YP. TGF-beta and BMP signaling in osteoblast, skeletal development, and bone formation, homeostasis and disease. Bone Res. 2016;4(1):16009. https://doi.org/10.1038/boneres.2016.9.

49. Chen G, Deng C, Li YP. TGF-beta and BMP signaling in osteoblast differentiation and bone formation. Int J Biol Sci. 2012;8(2):272-88. https:// doi.org/10.7150/ijbs.2929

50. Gerber HP, Dixit V, Ferrara N. Vascular endothelial growth factor induces expression of the antiapoptotic proteins $\mathrm{BCl}-2$ and $\mathrm{A} 1$ in vascular endothelial cells. J Biol Chem. 1998;273(21):13313-6. https://doi.org/10.1074/ jbc.273.21.13313.

51. Greenberg DA, Jin K. From angiogenesis to neuropathology. Nature. 2005; 438(7070):954-9. https://doi.org/10.1038/nature04481.

52. Rabelink TJ, Luscher TF. Endothelial nitric oxide synthase: host defense enzyme of the endothelium? Arterioscler Thromb Vasc Biol. 2006;26(2):26771. https://doi.org/10.1161/01.ATV.0000196554.85799.77.

53. Ahmad S, Hewett PW, Wang P, Al-Ani B, Cudmore M, Fujisawa T, et al. Direct evidence for endothelial vascular endothelial growth factor receptor1 function in nitric oxide-mediated angiogenesis. Circ Res. 2006;99(7):71522. https://doi.org/10.1161/01.RES.0000243989.46006.b9.

54. Rankin EB, Wu C, Khatri R, Wilson TL, Andersen R, Araldi E, et al. The HIF signaling pathway in osteoblasts directly modulates erythropoiesis through the production of EPO. Cell. 2012;149(1):63-74. https://doi.org/10.1016/j. cell.2012.01.051.

55. Teplyuk NM, Haupt LM, Ling L, Dombrowski C, Mun FK, Nathan SS, Lian JB, Stein JL, Stein GS, Cool SM, van Wijnen AJ. The osteogenic transcription factor Runx2 regulates components of the fibroblast growth factor/ proteoglycan signaling axis in osteoblasts. J Cell Biochem. 2009;107(1):14454. https://doi.org/10.1002/jcb.22108.

56. Biswas SK, Mantovani A. Macrophage plasticity and interaction with lymphocyte subsets: cancer as a paradigm. Nat Immunol. 2010;11(10):88996. https://doi.org/10.1038/ni.1937.

57. Julier Z, Park AJ, Briquez PS, Martino MM. Promoting tissue regeneration by modulating the immune system. Acta Biomater. 2017;53:13-28. https://doi. org/10.1016/j.actbio.2017.01.056.

58. Zheng ZW, Chen YH, Wu DY, Wang JB, Lv MM, Wang XS, Sun J, Zhang $Z Y$. Development of an accurate and proactive immunomodulatory strategy to improve bone substitute material-mediated osteogenesis and angiogenesis. Theranostics. 2018;8(19):5482-500. https://doi.org/10. 7150/thno.28315

59. Geng Y, Zhang L, Fu B, Zhang J, Hong Q, Hu J, Li D, Luo C, Cui S, Zhu F, Chen X. Mesenchymal stem cells ameliorate rhabdomyolysis-induced acute kidney injury via the activation of M2 macrophages. Stem Cell Res Ther. 2014;5(3):80. https://doi.org/10.1186/scrt469.

60. Luz-Crawford P, Jorgensen C, Djouad F. Mesenchymal stem cells direct the immunological fate of macrophages. Results Probl Cell Differ. 2017;62:61-72. https://doi.org/10.1007/978-3-319-54090-0_4.
61. Derynck R, Zhang YE. Smad-dependent and Smad-independent pathways in TGF-beta family signalling. Nature. 2003;425(6958):577-84. https://doi. org/10.1038/nature02006.

62. Karst M, Gorny G, Galvin RJ, Oursler MJ. Roles of stromal cell RANKL, OPG, and M-CSF expression in biphasic TGF-beta regulation of osteoclast differentiation. J Cell Physiol. 2004;200(1):99-106. https://doi.org/10.1002/ jсp.20036.

\section{Publisher's Note}

Springer Nature remains neutral with regard to jurisdictional claims in published maps and institutional affiliations.
Ready to submit your research? Choose BMC and benefit from:

- fast, convenient online submission

- thorough peer review by experienced researchers in your field

- rapid publication on acceptance

- support for research data, including large and complex data types

- gold Open Access which fosters wider collaboration and increased citations

- maximum visibility for your research: over $100 \mathrm{M}$ website views per year

At BMC, research is always in progress.

Learn more biomedcentral.com/submissions 